\title{
MONITORING THE CONTENT OF NITRATES IN VEGETABLES AND THE INFLUENCE OF THE PICKLING TECHNOLOGY ON THE DENITRIFICATION PROCESS
}

\author{
Mykola Kukhtyn \\ Department of Food Biotechnology and Chemistry \\ Ternopil I. Pul'uj National Technical University \\ 56 Ruska str., Ternopil, Ukraine, 46001 \\ kuchtynnic@gmail.com \\ Yulia Horiuk \\ Department of Infectious and Parasitic Diseases \\ State Agrarian and Engineering University in Podilya \\ 13 Schevchenka str., Kamianets-Podilskyi, Khmelnytskyi region, Ukraine, 32300 \\ goruky@ukr.net \\ Tetiana Yaroshenko \\ Department of Medical Biochemistry \\ I. Horbachevsky Ternopyl State Medical University \\ 1 Voli sq., Ternopil, Ukraine, 46001 \\ yaroshenkotya@tdmu.edu.ua \\ Svitlana Laiter-Moskaliuk \\ Department of Microbiology, Pharmacology and Animal Hygiene \\ State Agrarian and Engineering University in Podilya \\ 13 Schevchenko str., Kamianets-Podilskyi, Khmelnytskyi region, Ukraine, 32300 \\ layter.moskalyuk1977@gmail.com \\ Viktoria Levytska \\ Department of Infectious and Parasitic Diseases \\ State Agrarian and Engineering University in Podilya \\ 13 Schevchenko str., Kamianets-Podilskyi, Khmelnytskyi region, Ukraine, 32300 \\ levytska28@gmail.com \\ Antonina Reshetnyk \\ Department of Microbiology, Pharmacology and Animal Hygiene \\ State Agrarian and Engineering University in Podilya \\ 13 Schevchenko str., Kamianets-Podilskyi, Khmelnytskyi region, Ukraine, 32300 \\ anton56778192@gmail.com
}

\footnotetext{
Abstract

The aim of the work was to determine the concentration of nitrites in vegetable products (tomatoes, cucumbers, white cabbage, table beet, carrot, potatoes, onion and green onion, lettuce, spinach and parsley), realized at markets of the cities Ternopil, Kamianets-Podilskyi and Chernivtsi (Ukraine), to separate the distribution of nitrates in vegetables and also to study the influence of lactic microflora on the nitrate content at pickling tomatoes. It was established, that vegetables with the maximum exceed of maximum permissible concentration (MPC) by the nitrate content up to 1,6 times for products of closed soil are realized at markets. For open soil MPC exceed was in average 2,1 times. It was revealed, that most realized samples of tomatoes and leaf salad vegetables have the over-normative exceed of nitrates up to $35 \%$, and onion - the least one - $20 \%$. It was established, that nitrates accumulate in different parts of a fruit. In cucumbers, carrot, potato and table beet, the least quantity of nitrates accumulate in the external part of vegetables (near the surface), and the most one - in the central part. At the same time in cabbage and tomatoes, on the contrary, the least quantity - in the central part, the most one - in the area near the base of vegetables (stump). It was established, that at pickling tomatoes with the nitrate content within MPC lactic fermentation takes place with the intensive growth of titrated acidity, the decrease of the nitrate content takes place at this process. Under conditions of pickling tomatoes with the
} 
nitrate content two times more than MPC, the pickling process is a bit decelerated, but the nitrate content decreases to the safe level in a finished product. It was established, that vegetables with the nitrates quantity within $1500 \mathrm{mg} / \mathrm{kg}$ and more cannot be used in the pickling technology because of the bacteriological influence of nitrates on lactic microflora. Vegetables with such nitrate content must be obligatory condemned.

Keywords: nitrates content, vegetable products, pickling technology, denitrification, lactic microflora.

\section{Introduction}

Last time the influence of nitrates and nitrites on the human organism grew that was reflected on health [1]. This problem appeared, first of all, as a result of the system use of high doses of nitrogenous fertilizers. That is why the content of nitrates in vegetable products mainly depends on the uncontrolled use of nitrogenous fertilizers. Along with it nitrate food additives are the additional source of nitrogenous substances in animal products. Food additives are added in meat products for improving organoleptic parameters and inhibiting conventionally pathogenic microflora [2]. According to scientists' data, the important share of agricultural vegetable products in Ukraine includes nitrates in amounts that exceed the maximum permissible level (MPC) [3]. The permissible dose of nitrates for a human at taking by the organism with food products and water is $5 \mathrm{mg} / \mathrm{kg}$ a day $[4,5]$. The permissible day dose of nitrates for an average adult is near $325 \mathrm{mg}$ [6]. Coming in the human organism, nitrates are fast absorbed in the gastrointestinal tract, and then transform hemoglobin in methemoglobin, as a result the condition of hypoxia of cells appears $[5,7]$. But today the problem of the influence of nitrates on the human organism has mainly not acute, but chronic course [8]. As far as the organism compensate a certain part of nitrates effect, the chronic form is practically not diagnosed. Along with it, creation of strongly toxic N-nitrocompounds that are precursors of the big group of carcinogenic substances of nitrates in the gastrointestinal tract is possible $[5,6]$.

According to research data $[9,10]$ vegetable products, realized in Ukraine, contain $10-30 \%$ over-normative concentration of nitrates. Most of these products are realized in the spring-summer period. At that in some cases the nitrate content exceeds MPC in several times. Investigations inform that vegetables with the nitrate content more than the norm are also realized abroad [11-13]. So, different methods of decreasing nitrates quantity in vegetables before their consumption are offered. Thus, it was revealed, that the process of washing dill, lettuce, parsley and other green cultures that contain the very big quantity of nitrates decreases nitrates concentration up to $20 \%$. The process of two-hour soaking of these cultures in cold water decreases the nitrate content by 30-60\%. Boiling of potato, beet, carrot (after peeling and washing) allows to decrease the quantity of nitrates by $65,35,25 \%$, respectively [14-17]. But it is known, that the biological value also decreases at thermal processing. So the question of decreasing the nitrate content in vegetable products and also production of ready food products with the safe quantity of nitrates is the urgent problem till now.

Investigations that elucidate the presence of nitrates in preserved and pickles vegetables and fruits are practically not found. So, there are no enough data about the nitrate content in preserved products. There is also a little scientific information about the influence of lactic microflora on the nitrate content in pickling technologies.

Thus, taking into account negative results of effects of nitrates of food products on the human organism, it is necessary to organize monitoring studies of the quality of products and to use necessary technological means of processing that would give a possibility to decrease the nitrate content in food products, based on obtained data.

The aim of the work was to determine the concentration of nitrites in vegetable products (tomatoes, cucumbers, white cabbage, table beet, carrot, potatoes, onion and green onion, lettuce, spinach and parsley), realized at markets of the cities Ternopil, Kamianets-Podilskyi and Chernivtsi (Ukraine), to separate the distribution of nitrates in vegetables and also to study the influence of lactic microflora on the nitrate content at pickling tomatoes. 


\section{Materials and Methods}

\section{1. Materials and methods of the study of the nitrate content and microflora of salted tomatoes}

The studies were realized at the scientific-research laboratory of the department of food biotechnology and chemistry of Ternopil national technical university, named after I. Piluy (Ukraine). The first part of the studies was in monitoring of the nitrate content in vegetables, realized at agroproduction markets of Ternopil, Khmelnytsky, Chernivtsi and Lviv regions (Ukraine).

The second part of the studies investigated the influence of the technology of pickling tomatoes with the different nitrate content on the dynamics of the change of microflora quantity and denitrification process. Tomatoes with the nitrate content within MPC $-137 \pm 10 \mathrm{mg} / \mathrm{kg}$; two times more MPC $-619 \pm 32 \mathrm{mg} / \mathrm{kg}$ and 5 times more than MPC $-1576 \pm 114 \mathrm{mg} / \mathrm{kg}$ were used in the study. The experimental variants of tomatoes are presented on Fig. 1.

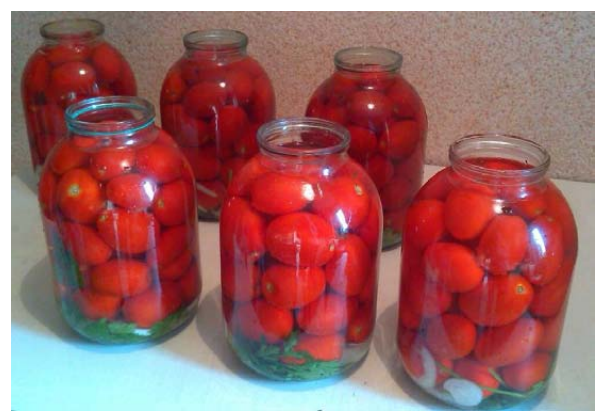

Fig.1. Experimental variants of tomatoes with the different nitrate content at pickling

The pickling technology provided pouring tomatoes with a pickle $(7,0 \%$ of sodium chloride) and preliminary fermentation at the temperature $25 \pm 1{ }^{\circ} \mathrm{C}$ during 24 hours up to milk acid accumulation in amount of $0,3 \%$. After preliminary fermentation tomatoes were finally fermented at the temperature $9 \pm 1{ }^{\circ} \mathrm{C}$ during 20-30 days. In the first day of pickling and after preliminary fermentation in 24 hours and in 10-20-30 days, the quantitative content of microflora, nitrate content, titrated acidity were determined in the pickle.

Nitrate content in vegetable products was determined by the ionometric method using the nitratometer H-401 (Ukraine) (Fig. 2).

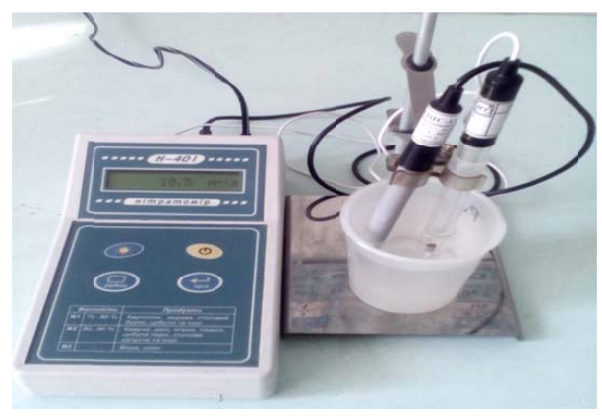

Fig. 2. Nitratometer device (H-401)

The essence of this method is in fact that nitrates are extracted from vegetable products by $1 \%$ solution of aluminium alums with the further measuring of their mass share.

Lactic microorganisms were determined on MRS-agar medium. Inoculations were incubated in the thermostat at the temperature $42{ }^{\circ} \mathrm{C}$ during 48 hours for determining thermophiles (optimal temperature for these bacteria) and at $37{ }^{\circ} \mathrm{C}$ during 48 hours for determining mesophiles (Fig. 3, a). Then the number of colony-forming units of microorganisms in $1 \mathrm{~cm}^{3}$ of the pickle was calculated. Bifidobacteria were determined on Bifidum-medium. Fir this aim $1 \mathrm{~cm}^{3}$ 
of tenfold solutions of the pickle was inoculated in $10 \mathrm{~cm}^{3}$ of medium, incubated in the thermostat at the temperature $37{ }^{\circ} \mathrm{C}$ during 48 hours and the number of colonies, formed in the medium, was calculated (Fig. 3, b).

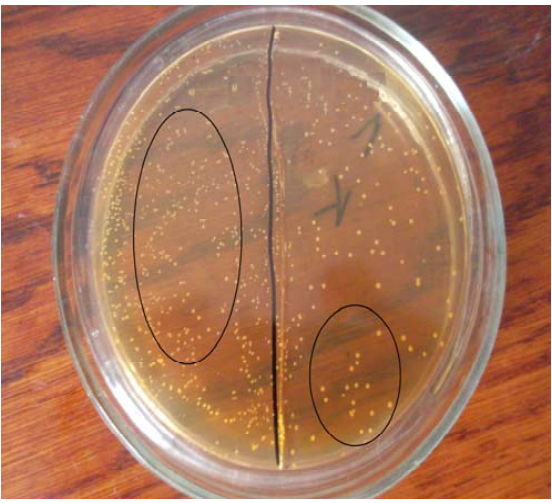

$a$

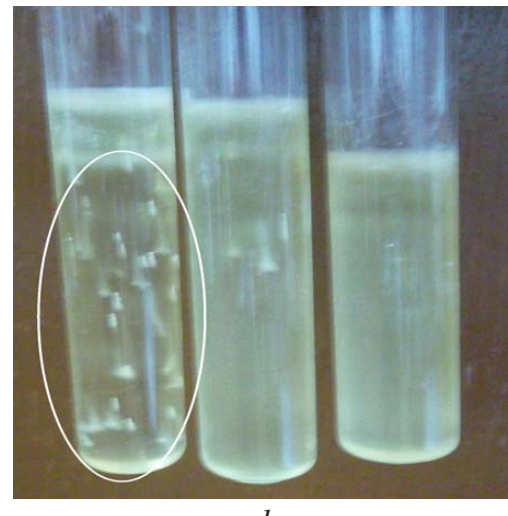

$b$

Fig. 3. Growth of colonies: $a$ - lactobacteria on $M R S$-agar medium in Petri dishes; $b$ - bifidobacteria in Bifidum-medium in test-tubes at inoculation of the pickle of salted tomatoes

Fungi and yeast were studied on Saburo medium at the incubation temperature in the thermostat $28^{\circ} \mathrm{C}$ during 3-5 days, daily observing the appearance of the growth of microorganisms (optimal conditions for fungi development). Spore-forming bacteria were determined on meat peptone agar (MPA) after preliminary keeping samples on the water bath at the temperature $85^{\circ} \mathrm{C}$ during $10 \mathrm{~min}$. Inoculations were incubated at $30^{\circ} \mathrm{C}$ during 72 hours (that is under classic standard incubation conditions). Clostridia were detected on Kitta-Tarocci medium at the temperature $37^{\circ} \mathrm{C}$, incubation of inoculations during 24 hours (optimal conditions for clostridia development). Titrated acidity was determined by the classic titrometric method [18].

\section{Results}

The results of the study of minimal and maximal quantities of nitrates in vegetable products, realized at markets of cities Ternopil, Kamianets-Podilskyi and Chernivtsi (Ukraine) are presented in Table 1.

\section{Table 1}

Quantities of nitrates in vegetable products, realized at markets of the cities Ternopil, Kamianets-Podilskyi and Chernivtsy, $\mathrm{n}=135$

\begin{tabular}{|c|c|c|c|c|}
\hline Vegetable products & Number of studied samples, $n$ & $\begin{array}{c}\text { Quantit } \\
\text { min }\end{array}$ & $\begin{array}{l}, \mathrm{mg} / \mathrm{kg} \\
\max \end{array}$ & $\mathrm{MPC}, \mathrm{mg} / \mathrm{kg}$ \\
\hline Tomatoes & 15 & 95 & 472 & $150 / 300$ \\
\hline Cucumbers & 15 & 112 & 564 & $200 / 400$ \\
\hline White cabbage & 15 & 309 & 1245 & $500 / 900$ \\
\hline Table beet & 15 & 612 & 2228 & 1400 \\
\hline Carrot & 15 & 129 & 621 & $250 / 400$ \\
\hline Potato & 15 & 78 & 347 & 250 \\
\hline Onion & 15 & 25 & 118 & 90 \\
\hline Green onion & 15 & 379 & 1254 & $600 / 800$ \\
\hline $\begin{array}{l}\text { Leaf salad vegetables } \\
\text { (lettuce, spinach, parsley) }\end{array}$ & 15 & 1870 & 4575 & $2000 / 3000$ \\
\hline
\end{tabular}

Note: MPC in the numerator-for open soil; in denominator-for close soil (hotbed) 
As it can be seen on the data of Table 1, vegetable products with the different nitrate content are realized at markets. The maximal exceed of MPC by the nitrate content was from 1,3 to 1,6 times for vegetables of close soil. For open soil MPC exceed was in average 2,1 times. The data as to the number of samples of vegetable products with the nitrate content more than MPC are presented on Fig. 4.

On Fig. 4 we can see that among studied realized vegetable products tomatoes and leaf salad vegetables had the over-normative nitrates content- $35 \%$ of samples. In average there were sold $30 \%$ of samples of cucumbers, cabbage, carrot and potato with the nitrate quantity more than MPC. The least number of samples with the nitrate content was revealed at realization of onions.

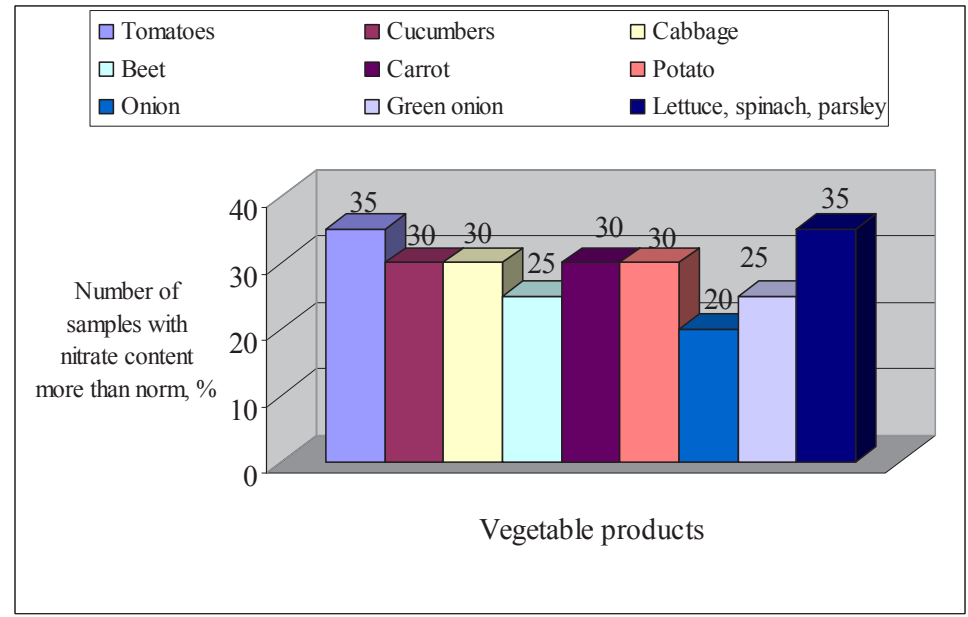

Fig. 4. Samples of vegetable products with the nitrate content more that the maximum permissible concentration, $\%, \mathrm{n}=135$

At studying the nitrate distribution in vegetables, it was established (Fig. 5), that in cucumbers, carrot, potato and table beet, the least quantity of nitrates accumulate in the external part of vegetables (near the surface), and the most one - in the central part. At the same time in cabbage and tomatoes, on the contrary, the least quantity - in the central part, the most one - in the area near the base of vegetables (stump).

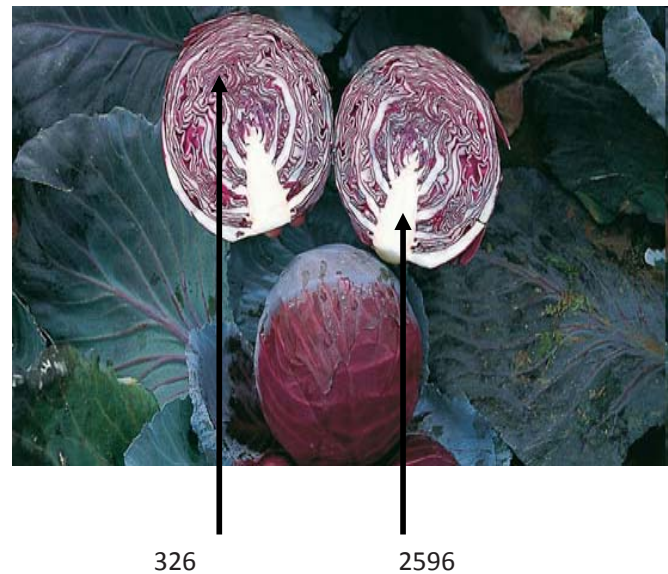

$a$

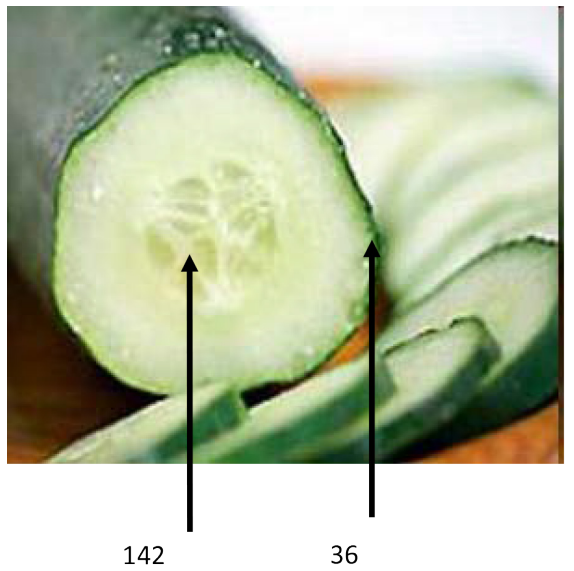

$b$

Fig. 5. Distribution of nitrates in vegetables: $a$ - in cabbage; $b$ - in cucumbers, $\mathrm{mg} / \mathrm{kg}$

So the studies indicate that realized vegetable products with the essential content of nitrates are dangerous for consumers' health, because it can cause food intoxications [6, 7]. That is why there was offered to use vegetables with the over-normative content of nitrates in the pickling 
technology. At such processing way the denitrification process takes place under the influence of lactic microorganisms, and the nitrate quantity in a ready product doesn't exceed MPC. As an example, Table 2 presents the data of the influence of the tomato picking technology with the different nitrate quantity on the development of lactobacteria and denitrification process.

Table 2

Characteristics of lactic and denitrification processes at pickling tomatoes with the different nitrate quantity

\begin{tabular}{|c|c|c|c|c|c|c|}
\hline \multirow{2}{*}{$\begin{array}{c}\text { Hours, days of } \\
\text { pickling }\end{array}$} & \multicolumn{2}{|c|}{$\begin{array}{l}\text { Initial quantity of nitrates in } \\
\text { tomatoes } 137 \pm 10 \mathrm{mg} / \mathrm{kg}\end{array}$} & \multicolumn{2}{|c|}{$\begin{array}{c}\text { Initial quantity of nitrates in } \\
\text { tomatoes } 619 \pm 32 \mathrm{mg} / \mathrm{kg}\end{array}$} & \multicolumn{2}{|c|}{$\begin{array}{l}\text { Initial quantity of nitrates in } \\
\text { tomatoes } 1576 \pm 114 \mathrm{mg} / \mathrm{kg}\end{array}$} \\
\hline & Titrated acidity & $\begin{array}{l}\text { Nitrate } \\
\text { quantity }\end{array}$ & Titrated acidity & $\begin{array}{l}\text { Nitrate } \\
\text { quantity }\end{array}$ & $\begin{array}{c}\text { Titrated } \\
\text { acidity }\end{array}$ & Nitrate quantity \\
\hline $\begin{array}{l}\text { Fresh pickle at tem- } \\
\text { perature } 25 \pm 1{ }^{\circ} \mathrm{C}\end{array}$ & 0 & $137 \pm 10$ & 0 & $619 \pm 32$ & 0 & $1576 \pm 114$ \\
\hline $\begin{array}{l}\text { In } 24 \text { hours of active } \\
\text { fermentation at tem- } \\
\text { perature } 25 \pm 1{ }^{\circ} \mathrm{C}\end{array}$ & $0,29 \pm 0,02$ & $121 \pm 7$ & $0,20 \pm 0,02$ & $567 \pm 30$ & 0,1 & $1576 \pm 112$ \\
\hline $\begin{array}{l}\text { In } 10 \text { days at tem- } \\
\text { perature } 9 \pm 1{ }^{\circ} \mathrm{C}\end{array}$ & $0,47 \pm 0,03$ & $60 \pm 4$ & $0,39 \pm 0,02$ & $269 \pm 27$ & 0,1 & $1620 \pm 113$ \\
\hline $\begin{array}{l}\text { In } 20 \text { days at tem- } \\
\text { perature } 9 \pm 1^{\circ} \mathrm{C}\end{array}$ & $0,63 \pm 0,04$ & $44 \pm 3$ & $0,58 \pm 0,03$ & $193 \pm 17$ & 0,1 & $1584 \pm 111$ \\
\hline $\begin{array}{l}\text { In } 30 \text { days at tem- } \\
\text { perature e } 9 \pm 1{ }^{\circ} \mathrm{C}\end{array}$ & $0,71 \pm 0,04$ & $28 \pm 2$ & $0,70 \pm 0,04$ & $132 \pm 9$ & 0,1 & $1513 \pm 110$ \\
\hline
\end{tabular}

As it can be seen on Table 2, the growth of titrated acidity 0,29 $\pm 0,02$ un took place in tomatoes with the nitrate content within MPC $137 \pm 10 \mathrm{mg} / \mathrm{kg}$ already during active fermentation that indicate the development of lactic microorganisms. The nitrate quantity decreased in this period of time not essentially to $121 \pm 7 \mathrm{mg} / \mathrm{kg}$. During next ten days of fermentation the development of lactic bacteria caused the growth of titrated acidity in 1,6 times, and the nitrate quantity decreased in 2,0 times compared with the first day of pickling.

From the tenth to thirtieth day of fermentation there took place intensive lactic fermentation, as a result of which titrated acidity increased in 1,6 times to $0,71 \pm 0,04$ un, and the nitrate content decreased in 2,1 times and was $28 \pm 2 \mathrm{mg} / \mathrm{kg}$.

The practically analogous tendency of the dentrification process was observed also at the nitrate content in tomatoes two times more than MPC $(619 \pm 32 \mathrm{mg} / \mathrm{kg})$ that characterized by the gradual growth of titrated acidity and decrease of the nitrate content. The differences were only in certain deceleration of the titrated acidity growth in first ten days of pickling. Some decrease of the titrated acidity growth is connected with the bacteriostatic influence on lactic microflora. But after finishing the pickling process the nitrate quantity in ready tomatoes was $132 \pm 9 \mathrm{mg} / \mathrm{kg}$.

At the assessment of the pickling technology of tomatoes with the nitrate content 5 times more than MPC $(1576 \pm 114 \mathrm{mg} / \mathrm{kg})$ it was established, that the growth of titrated acidity doesn't take place during the whole period. It indicates the absence of lactic microflora propagation and manifestations of denitrification properties. That is the nitrate concentration in tomatoes within $1500 \mathrm{mg} / \mathrm{kg}$ has the bacteriostatic influence of lactobacteria and pickling doesn't take place. So, taking into account the fact that pickling is based on the development of lactic microflora, it can be used for processing many kinds of vegetables. Thus, these studies indicate that vegetable products with the nitrate content two times more than MPC within $600-700 \mathrm{mg} / \mathrm{kg}$ can be used in the pickling technology.

\section{Conclusions}

It was established, that vegetables with the maximum exceed of MPC by nitrate content from 1,3 up to 1,6 times for products of closed soil are realized at markets. For open soil MPC exceed was in average 2,1 times. It was revealed, that most realized samples of tomatoes and leaf salad vegetables have the over-normative exceed of nitrates up to $35 \%$ of samples. The least number of samples with the nitrate content was revealed at onions realization. It was established, that nitrates accumulate in different parts of a fruit. 
It was established, that at pickling tomatoes with nitrate content within MPC lactic fermentation takes place with the intensive growth of titrated acidity, the decrease of the nitrate content takes place at this process. Under conditions of pickling tomatoes with nitrate content two times more than MPC, the pickling process is a bit decelerated, but the nitrate content decreases to the safe level in a finished product. It was established, that vegetables with nitrates quantity within $1500 \mathrm{mg} / \mathrm{kg}$ and more cannot be used in the pickling technology because of the bacteriological influence of nitrates on lactic microflora. Vegetables with such nitrate content must be obligatory condemned.

The obtained data indicate the necessity of continuous monitoring studies of the nitrate content in vegetables and allow to recommend the biological process of pickling for preserving vegetable products with the over-normative nitrate content. But at realization at markets or processing at plants the determination of the nitrate content in vegetable products is not always carried out, so they are processed without taking this parameter into account. So, these studies allow to recommend vegetables with the nitrate content more than the maximum permissible concentration for pickling processing.

\section{References}

[1] Kharitonov, M. M., Lazareva, O. M., Lemishko, S. M. (2015). Environmental assessment of the variability of nitrate content in vegetable and fruit and berry crops in the Dnipropetrovsk region. Newsletter of the Poltava State Agrarian Academy, 3, 29-31.

[2] Hord, N. G., Tang, Y., Bryan, N. S. (2009). Food sources of nitrates and nitrites: the physiologic context for potential health benefits. American Journal of Clinical Nutrition, 90 (1), 1-10. doi: 10.3945/ ajcn.2008.27131

[3] Merino, L., Ornemark, U., Toldra, F. (2017). Analysis of Nitrite and Nitrate in Foods. Advances in Food and Nutrition Research, 65-107. doi: 10.1016/bs.afnr.2016.11.004

[4] Davidovskyi, A. H. (2009). Metabolycheskaia korrektsyia redoks-statusa erytrotsytov pry bakteryalnoi endotoksemyy y nytryt yndutsyrovannoi methemohlobynemyy. Zdorove y okruzhaiushchaia sreda, $13,317-323$.

[5] Tociu, C., Marcu, E., Ciobotaru, I. E., Maria, C. (2016). Risk assessment of population exposure to nitrates/nitrites in groundwater: a case study approach. ECOTERRA - Journal of Environmental Research and Protection, 13 (3), 39-45.

[6] Quijano, L., Yusa, V., Font, G., McAllister, C., Torres, C., Pardo, O. (2017). Risk assessment and monitoring programme of nitrates through vegetables in the Region of Valencia (Spain). Food and Chemical Toxicology, 100, 42-49. doi: 10.1016/j.fct.2016.12.010

[7] Iammarino, M., Di Taranto, A., Cristino, M. (2013). Endogenous levels of nitrites and nitrates in wide consumption foodstuffs: Results of five years of official controls and monitoring. Food Chemistry, 140 (4), 763-771. doi: 10.1016/j.foodchem.2012.10.094

[8] Musiyenko, M. T., Kryzhanivskyy, Ya. Y., Kukhtyn, M. D., Danylenko, I. P. (2008). Vmist nitrativ u molotsi ta methemohlobinu $\mathrm{v}$ krovi koriv yak pokaznyk zhyvylnoyi tsinnosti zymovykh ratsioniv. Naukovyy viznyk Lvivskoho natsionalnoho universytetu veterynarnoyi medytsyny ta biotekhnolohiyi im. S. Z. Gzhyts'koho, 3 (10 (38)), 162-165.

[9] Zasypka, L. H., Vorokhta, Yu. M., Stepanova, L. V., Babiienko, V. V. (2008). Problema zabrudnennia ovochevoi produktsii nitratamy. Problemy kharchuvannia, 3-4, 32-34.

[10] Valerko, R. A. (2013). Otsinka rivnia zabrudnennia roslynnytskoi produktsii, vyroshchenoi v umovakh m. Zhytomyr. Visnyk derzhavnoho ahroekolohivchnoho universytetu, 1, 356-366.

[11] Tamme, T., Reinik, M., Roasto, M., Juhkam, K., Tenno, T., Kiis, A. (2006). Nitrates and nitrites in vegetables and vegetable-based products and their intakes by the Estonian population. Food Additives and Contaminants, 23 (4), 355-361. doi: 10.1080/02652030500482363

[12] Chung, S. Y., Kim, J. S., Kim, M., Hong, M. K., Lee, J. O., Kim, C. M., Song, I. S. (2003). Survey of nitrate and nitrite contents of vegetables grown in Korea. Food Additives and Contaminants, 20 (7), 621-628. doi: 10.1080/0265203031000124146

[13] Pardo-Marin, O., Yusa-Pelecha, V., Villalba-Martin, P., Perez-Dasi, J. A. (2010). Monitoring programme on nitrates in vegetables and vegetable-based baby foods marketed in the Region of Valencia, Spain: levels and estimated daily intake. Food Additives \& Contaminants: Part A, 27 (4), 478-486. doi: 10.1080/19440040903439804

[14] Min, J., Zhang, H., Shi, W. (2012). Optimizing nitrogen input to reduce nitrate leaching loss in greenhouse vegetable production. Agricultural Water Management, 111, 53-59. doi:10.1016/ j.agwat.2012.05.003 
[15] Inoue-Choi, M., Virk-Baker, M. K., Aschebrook-Kilfoy, B., Cross, A. J., Subar, A. F., Thompson, F. E., Sinha, R., Ward, M. H. (2015). Development and calibration of a dietary nitrate and nitrite database in the NIH-AARP Diet and Health Study. Public Health Nutrition, 19 (11), 1934-1943. doi: 10.1017/ s1368980015003407

[16] Bahadoran, Z., Mirmiran, P., Jeddi, S., Azizi, F., Ghasemi, A., Hadaegh, F. (2016). Nitrate and nitrite content of vegetables, fruits, grains, legumes, dairy products, meats and processed meats. Journal of Food Composition and Analysis, 51, 93-105. doi: 10.1016/j.jfca.2016.06.006

[17] Habermeyer, M., Roth, A., Guth, S., Diel, P., Engel, K.-H., Epe, B., Furst, P., Heinz, V., Humpf, H.-U., Joost, H.-G., Knorr, D., de Kok, T., Kulling, S., Lampen, A., Marko, D., Rechkemmer, G., Rietjens, I., Stadler, R. H., Vieths, S., Vogel, R., Steinberg, P., Eisenbrand, G. (2014). Nitrate and nitrite in the diet: How to assess their benefit and risk for human health. Molecular Nutrition \& Food Research, 59 (1), 106-128. doi: 10.1002/mnfr.201400286

[18] Kukhtyn, M., Vichko, O., Berhilevych, O., Horyuk, Y., Horyuk, V. (2016). Main Microbiological and Biological Properties of Microbial Associations of Lactomyces tibeticus. Research Journal of Pharmaceutical, Biological and Chemical Sciences, 7 (6), 1266-1272.

\title{
DEFINITION OF QUALITY INDICATORS OF DAIRY- PROTEIN CONCENTRATES IN THE STORAGE PROCESS
}

\author{
Victoriya Gnitsevych \\ Department of Technology and the organization of restaurant business \\ Kyiv National University of Trade and Economics \\ 19 Kyoto str., Kyiv, Ukraine, 02156 \\ flamber1965@gmail.com \\ Tatiana Yudina \\ Department of Technology and the organization of restaurant business \\ Kyiv National University of Trade and Economics \\ 19 Kyoto str., Kyiv, Ukraine, 02156 \\ olegdmu@rambler.ru
}

Liudmyla Deinychenko

Department of commodity science, management of safety and quality

Kyiv National University of Trade and Economics

19 Kyoto str., Kyiv, Ukraine, 02156

deliugri@gmail.com

Radion Nykyforov

Department of technology in a restaurant economy that hotel and restaurant business

Donetsk National University of Economics and Trade named after Mykhailo Tugan-Baranovsky 16 Ostrowski str., Krivoy Rog, Ukraine, 50005

nykyforov@donnuet.edu.ua

Iryna Nazarenko

Department of technology in a restaurant economy that hotel and restaurant business

Donetsk National University of Economics and Trade named after Mykhailo Tugan-Baranovsky

16 Ostrowski str., Krivoy Rog, Ukraine, 50005

Nazarenko@donnuet.edu.ua

\footnotetext{
Abstract

The aim of this article is to investigate changes in the structure, color and microbiological parameters of milk-protein concentrates (MPC) made of buttermilk with the use of cranberry or viburnum purees in the process of storage. Necessary results were obtained after analyzing phase transitions, changes in color-parametric and microbiological characteristics of the studied products.
} 